This work is licensed under a Creative Commons Attribution 4.0 International License.

Ovaj rad dostupan je za upotrebu pod licencom Creative Commons Imenovanje 4.0 međunarodna.

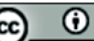

Jelena ŠESNIĆ

UDK $821.111(73) .09$ Jewett, S. O.-31

Faculty of Humanities and Social Sciences

University of Zagreb

DOI:https://doi.org/10.29162/ANAFORA.v6i2.8

Ivana Lučića 3, HR - 10000 Zagreb

jsesnic@ffzg.hr

Izvorni znanstveni članak

Original Research Article

Primljeno 21. veljače 2019.

Received: 21 February 2019

Prihvaćeno 2. prosinca 2019.

Accepted: 2 December 2019

\title{
THE PAST AND PRESENT OF AGE AND AGEING IN THE COUNTRY OF THE POINTED FIRS AND OLIVE KITTERIDGE
}

\begin{abstract}
The text examines the well-known late-nineteenth century novel The Country of the Pointed Firs (1896) by Sarah Orne Jewett and the early twenty-first century novel Olive Kitteridge (2008) by Elizabeth Strout, and sets them in several distinct but intersecting contexts within a larger argument about the reading methodology motivated by age studies and their growing appreciation in the humanities. This argument is then extended in the sections focusing on pastoralism and the way it incorporates, or evades, the question of age and ageing. The next section takes up the possibilities opened up by the pastoral mode and links them to another strain of fiction to which both texts belong despite the temporal distance, that of regionalism and its long tradition specifically in New England fiction examined from the vantage point of age. Finally, the last section of the argument adds further considerations not only of the parallels but also of telling differences between the two texts due to the different temporal and cultural context in which they strive to represent age and ageing. By focusing on emotions and their display as part of the narrative of ageing, both texts (Olive Kitteridge in particular) meaningfully illustrate the issue of age with its many ramifications for the contemporary Western societies. The two texts
\end{abstract}


thus show a transition in American culture in the representations of age and ageing from its pre-scientific phase (in Jewett's text) to the current medicalized and scientific view of age and its consequences (in Strout's text).

Keywords: Age Studies, The Country of the Pointed Firs, Olive Kitteridge, pastoralism, regionalism, emotions

\section{Introduction: Reading and Age}

In a recent thematic cluster "Reading over Time" hosted by PMLA and dedicated to the intersection of reading and age, the contributors respond to an interesting, if somewhat puzzling, query: does our reading change (and how) when we focus on the theme of age and how does our reading shift with age and ageing? As their thoughts range from addressing the inevitable and swift change of reading paradigms within the discipline of literary studies to more intimate accounts of the ways the passing of time affects a scholar's re-reading of a novel, they allow us to consider the ways age becomes one of key features for apprehending texts in conjunction with other salient critical categories (race, class, gender, etc.). Surprisingly, however, as Cynthia Port points out in her response, "Age ... was not being similarly theorized as a category of analysis, leaving even a critically engaged reader with few tools with which to counter the age-related expectations and ageist assumptions that pervade cultural narratives" (642). This oversight is all the more glaring since, as Post continues, "at a time when humanities scholars were publishing widely on numerous aspects of identity and difference, conceptions of age - the only aspect of identity that universally and inevitably changes over time-were not similarly explored" (643).

It would be preposterous to advance a conclusive or even a proximate explanation for this omission or repression by literary criticism and theory in the U.S. American context, but several tentative proposals might be made in this respect. The first tentative answer might be that American culture is a culture obsessed with strength, prowess, ability (physical and mental), mobility, and adventuri$\mathrm{sm}$, all traits that are explicitly associated with youth. The mythic figures that populate the popular national imaginary are cowboy, pioneer, trapper, soldier, all of whom radiate the aura of youthful endurance and strength. On the feminine side, the figures are less striking but, as was the case with their masculine counterparts, they certainly require a degree of pluck and capability ascribed to the young age, as in the image of the flapper, the New Woman, or, in an even 
more popular context, the pin-up girl. These images of women suggested the idea of youthful wholesomeness and physical beauty untainted by age. ${ }^{1}$

The next tentative answer would have to do with the institutional setting in which the study of literature takes place, and which requires the relatively quick change of models and paradigms of reading so as to lend credibility and internal logic to the institutionalized study of literature and the humanities. In that sense, there is no time for a paradigm to mature and grow old since one reading model will rather promptly be superseded by another, newer and more sophisticated, "younger" model. It is therefore the way a discipline or an institutional practice renews and legitimizes itself (Lanser 654-55).

It is worth adding another entrenched reason for a continuing revulsion to and erasure of age, provided by Kathleen Woodward. It is the matter of our congenital, evolutionary fear of death and our personal biological extinction that urges us to overlook the destiny that, if nothing else, awaits us all:

I agreed then, and I do now, that a protective reflex to shield ourselves from decline and death might contribute to producing an individual's willful blindness toward their own aging as well as neglect on the part of society as a whole. But certainly ... thistotalizing argument of "repulsion"-of deep-seated aversion-had something strange and extreme about it. (Woodward "Re-reading")

Accordingly, it is not surprising that age is still understudied in the humanities, as Woodward contends.

As a counter-response, we might no longer have the leisure not to think about the cultural, biological, and psychological implications of aging. The answer what makes it so has to do with the processes of long duration and major demographic shifts that in the last decades have overtaken the West and have been registered in either sober or alarming tones across a range of disciplines in the humanities and social sciences, and can be summed up as follows: the Western

The classic articulations of these ideas are, for instance, the Adamic myth, which while not explicitly positing the youth of the mythic hero, nevertheless implies it unmistakably (Lewis). D.H. Lawrence's (1923) early incisive readings of American culture also take the youthful age of a self-inventive, self-regenerative man almost for granted. Emerson's ideal of the "American Scholar," or a self-reliant man, is redolent of the self-assuredness of youth or at least of an endlessly rejuvenating individual (Emerson). For the women's side of the story, see Banta, Earnest (pre-ageing studies); McGlynn et al, Morganroth Gullette (from the perspective of ageing studies). 
societies are on the whole becoming older, the majority of their populations are aged or ageing, the baseline biological reproduction is not adequate to ensure the viability of a society in its different functions, all of which suggests that we need to see how a society is supposed to deal with these apparently irreversible but quite consequential changes. This is why increasingly we find scholars in various disciplines and in the interdisciplinary field turn to the study of age and ageing. ${ }^{2}$

Given the above mentioned argument, this article advances a contention that age matters in literary studies (Post 644) and looks into the ways the reading within Age Studies might enhance our understanding of particular texts in American culture and therefore also of American culture as a whole. The contention will be briefly tested on two texts that lend themselves to reading through the categories of Age Studies, although not frequently read in that vein, Sarah Orne Jewett's classical and canonical novel (or cycle of stories) The Country of the Pointed Firs (1896) and Elizabeth Strout's recent novel (or cycle of stories) Olive Kitteridge (2008). ${ }^{3}$ Since in the remainder of the discussion the choice of considering together these two distant texts will be further clarified, at this point let it be signaled that both Jewett's and Strout's texts lend themselves to the reading in terms of the issues of age and ageing: the protagonists and narrators in both are elderly women, the widowed Almira Todd (in Jewett's novel) and Olive Kitteridge (in Strout's novel), first as a married woman, then as a widow. The demographics of the Maine sea towns where both reside (even though Jewett's Dunnet Landing is fictional, while Strout's Crosby is found on the map) comprise different age groups, each with their own concerns, which taken together

2 Once we go in this direction, other interesting paths of inquiry open up, such as in considering the importance of demographics for the study of societal trends; how the sheer population growth and number of people in a particular age cohort may set down priorities for social inquiry, as pointed out by Charles Murray in his recent study. Writing about the mid-1960s and landmark changes sweeping over the United States, Murray states: "And history has already swallowed the demographic pig. The leading cohorts of the baby boomers were in their teens by November 21, 1963 [J.F. Kennedy's assassination], and, for better or worse, they were going to be who they were going to be. No one understood at the time what a big difference it could make if one age group of a population is abnormally large. Everybody was about to find out" (11). It is hardly an overstatement that demography matters, but it still remains to be seen how this cluster is understood in the humanities. In a similar vein, Kathleen Woodward reports Betty Friedan's observation how the women's movement in the 1960s was born as a result of attained longevity across the board and, specifically, of women's increased life expectancy, which is a thought deserving credit (Statistical Panic 68).

3 For a more expansive list of critical sources on Jewett's novel, see The Sarah Orne Jewett's Text Project, in particular, "Literary Scholarship and Writing about Sarah Orne Jewett." 
weave a web of a local community in their respective periods. Additionally, it is hard to miss Strout's obvious homage to her regional predecessor as seen in the format of her stories. To sum up, both fictions intertwine "the human and natural landscape of New England" (Howard 2) but do it at discrete historical points.

In broader terms, we might say that the insertion of age in literary studies is part of a more sweeping recent trend, as pointed out by Philip Fisher, who writes the following in 1999:

In recent decades, perhaps for the first time, a culture of senior citizens has come into being with its own way of life, recognizable clothing, retirement communities, perhaps even states (Florida and Arizona), its own types of entertainment, political representation, and so on. The American Association of Retired Persons (AARP) is now a more profound membership in America than the Irish-American Club, the Sons of Italy, or the Croatian Catholic Church [sic]. (Still the New World 162)

The intriguing questions to consider are: how has this affiliated membership in an age group turned into one of the striking facts of American (and, we might add, Western) cultural life and what does it do to other types of "loyalties" (Geertz qtd. in Still the New World 169) and associations?

\section{1. "Et in Arcadia Ego": Age and the Pastoral}

In her informative overview of Jewett's critical fortunes in American literary history, June Howard notes an interesting remark made by Willa Cather about the status of Jewett's by then best-known and most praised text, The Country of the Pointed Firs, where Cather groups Jewett's novel with the likes of The Adventures of Huckleberry Finn and The Scarlet Letter, since, as Cather further argues, their structure figures the pastoral retreat and return in a complex design (qtd. in Howard 1). This remark by one of Jewett's shrewdest and most engaging critics will provide a lead into the following section of the argument.

That Jewett's texts have understandably been read under the sign of pastoralism is indicated by a specific type of narrator in her text, observed upon by a number of critics, who note the narrator's flight from the city (civilization) to the country, the presumably unspoiled space of rural Maine, where the anonymous writer seeks refuge and inspiration for her work (Fetterley and Pryse 212). This rather simple impulse, however, carries deep and complex cultural assumpti- 
ons, as pointed out by Leo Marx, illustrative of some underlying concepts about American culture (9-10). This "withdrawal from society into idealized landscape" (Marx 10) is a major cultural pattern, having to do with images of space. To go on with Marx's thoughts, Jewett's Maine at this point in time still retains the features of what Marx terms the middle ground, or the place that holds the balance between (cultivated) nature and (overwrought) civilization. Maine can be seen in Jewett's vision still as a landscape where "the self and the environment" stand in the balance (Marx 13). Even though there is a definite spatial slant in the notion of pastoralism, reinforced by Jewett's images of the rural Maine, the following paragraphs attempt to offer a reading of the pastoral from the angles of age, ageing, and temporality, and will gradually ease into the argument.

Accordingly, when the narrator (of unspecified age, except that she herself is no longer young, even when compared to her landlady, impressive Mrs. Todd and her mother, old but sprightly Mrs. Blackett [Novels and Stories 471]), arrives at Dunnet Landing for the summer, she enacts a temporary retreat from the city into "the village ... so still that I could hear the whippoorwills singing that night as I lay awake in my downstairs bedroom, and the scent of Mrs. Todd's herb garden under the window blew in again and again with every gentle rising of the sea-breeze" (Novels and Stories 420), while the image of the garden figures as the middle ground, a meeting point of the natural and the man-made. ${ }^{4}$ Arriving in the "coast town of Dunnet Landing," "a single passenger" cherishes "childish certainty of [it] being the center of civilization of which her affectionate dreams had told" (Novels and Stories 377). In more emphatic terms, "[i]t was a return to happiness" (Novels and Stories 556). The urbanite's world frustrates her with "the complexity and futile ingenuity of social life" in a city and leads to the writer's block, which can be alleviated only in pastoral surroundings of the backward New England region of "eastern Maine" (Novels and Stories 377). The result of her summer-long sojourn in Dunnet Landing has had a profound effect on the narrator, who now reluctantly needs to "return to the world in which I feared to find myself a foreigner," deeply impressed by "the ease that belongs to simplicity" of the rustic life (Novels and Stories 484). She is virtually regenerated by her stay in the place whose combination of natural and social features "made

Leo Marx's study offers an excellent and still relevant discussion of the importance of particular types of places that might lodge the pastoral ideal, the garden being one such. Lawrence Buell also points to "the garden and the rural landscape" as the middle ground, the locus amoenus of the pastoral (440 n. 4). 
me feel solid and definite again, instead of a poor, incoherent being" (Novels and Stories 556).

It is interesting to note that pastoralism implies retreat not only in place but also in time, and that it therefore features a special kind of temporality, the one that arrests the passage of time and stalls change. As if to tout this view of time, the narrator deliberately casts one of the principal denizens of Dunnet Landing, Mrs. Todd, an elderly widow, as a quasi-mythical character. Drawing on her role of a local herbalist, the narrator casts her as "a huge Sybil" (Novels and Stories 381), "a caryatide," an "enchantress" (Novels and Stories 401). If, arguably, this is not specific enough for what is contended here, at other points in the text Mrs. Todd acquires the endearing, but also just a little bit over-the-top nickname of "rustic philosopher" (Novels and Stories 403), while the salience is kept up at another moment, when during their expedition in the woods to gather herbs Mrs. Todd strikes the narrator as "Antigone alone on the Theban plain" (Novels and Stories 417). Even more telling for the illusion of timelessness enveloping this axial character, the pillar of the community, is another occasion where the narrator observes: "She [Mrs. Todd] might belong to any age, like an idyl [sic] of Theocritus" (Novels and Stories 424). This idealized reading, however, tells just one side of the story since it is obvious that from very early on attempts were made to insert the question of temporality, and more importantly, mortality, into the main frame of the genre. Visualizing time in the genre of pastoral painting, Erwin Panofsky famously pointed to a tradition of infusing the pastoral with questions of age, ageing, and resultant death, weaving a story of a steady relationship between the two (qtd. in Gifford 154).

Another oblique way of inserting temporality into the pastoral tradition is to consider its topicality as we register the range of themes represented in the texts considered as such, insofar as they would seem to relate, overtly or covertly, to their immediate context. Leo Marx provides us with an entry point even here, when he contends that pastoralism is a response to political concerns (20), and it is therefore necessary to look into political overtones of the ideal in Jewett's text.

A set of political ideas tied to pastoralism is carried over from its early articulation in the American context brought forth by Thomas Jefferson. In his seminal Notes on the State of Virginia, Jefferson implies that the rural world, and its self-sufficient and wholesome economy, is morally and metaphysically supe- 
rior to the urban, commercial forces. That being the case, Jefferson continues, America should retain its agricultural bent and refuse to accommodate either manufacturing or trading interests. If these two are successfully kept out of the republic, Jefferson is confident that the republican principles will prosper and that republican men will maintain a healthy, vital relationship with the land and with the polity. For Jefferson thus, the cultivated land, small-scale farm holdings capable of providing subsistence to families and the growing population (which is not a problem precisely since there is much available land and still not so many people), is a prerequisite and the warranty of democracy, and expressive of the nation's character (Jefferson).

This way of politicizing pastoralism, construing it as a container of the national identity, finds its way into Jewett's text in multiple ways as shown by revisionist readings of the novel as a result of the infusion of new paradigms into American Studies in the late twentieth century (Howard's excellent collection illustrates the trend). Pastoralism, as claimed by successive critics, could subsist hand in hand with imperialism, industrialism, nationalism, and nativism, and act as a screen against which to project the attitudes and anxieties the American cultural mainstream harbored at the turn of the twentieth century. Given the previous argument that the pastoral seeks to contain temporality and arrest time, the genre was made to accommodate the complex, anxious, and unnerving reactions to varied social changes overtaking turn-of-the-century American society. Sandra Zagarell, one of the critics who champions the notion of community in the work of Jewett as a way to reclaim the writer and her work for the feminist literary history, still has no qualms to note the author's "genteel elitism" and "deep-seated nativism" shared by other Boston Brahmins (41). Howard seconds this observation by suggesting that the text should be read as an insight into how "elite New Englanders" perceive the issues that disturb the country (11). Zagarell further argues that "the association of a village community with the 'true' America is ... characteristic of the literary tradition to which [Jewett's work] belongs" (42-3).

The pastoral ideal, however ill- or well-disposed to address the topical issues, might also be charged with a certain degree of escapism, as evident in the motifs of retreat or recurrent return (from the place of simplicity and safety to the urban chaos and back). Certainly, one should acknowledge the limits of pastoralism where it has to face reality, a point clearly articulated already in Marx's seminal study. There is, however, a hospitable place of refuge where pastoralism might 
subsist and flourish despite the contrarian tendencies in turn-of-the-century America, and that refuge is regional literature, a form of "minor writing" employing realist procedures and expanding on the national scale in the post-Civil War period (from the 1860s to '90s). Political articulations seem to resonate in the ambit of a specific representational mode current in late-nineteenth-century American culture as it sought to grapple with the immense societal changes. As Philip Fisher puts it in the context of his discussion on regionalism, "As a literary-cultural movement we identify it [regionalism] with a resistance to modernity in the name of the older, even if not traditional, ways of life, with a hostility to the growing importance of urban culture, and with a defiance of or resistance to the homogenized economy-the market as it is sometimes called. . ." (Still the New World 174). Regionalism adopts and appropriates the pastoral focus on a particular place, now a region, and intends to represent a "place-centered" variant of the nation (Brodhead 116).

The idea that Dunnet Landing, the locus of Jewett's stories, stands for a local and organic image of a community (Zagarell 44) would imply that its villagers contain the virtues and features of the proper national subjects, especially at a time when the organic nature of many other communities (urban rather than rural) was under siege by strangers, the newly arrived immigrants. The mantle of pastoralism could be used to argue for a pre-lapsarian state of the country and the nation where some manner of balance still obtained between men, women, and their environment. Critical interventions, however, make us realize how carefully constructed the image of the organic community must be and how Jewett's narrative has to obviate the facts of history in order to cast about for an image of the pastoral retreat. Reinforcing this bleaching of history is Marx's observation that in pastoralism a rural world is seen as morally and metaphysically superior to the urban, commercial forces (99). Similarly, in a recent reading of regional fiction, Stephanie Foote contends that regional fiction presents "nostalgic portraits of pre-industrial rural communities and people" (3).

Dunnet Landing as a local and organic community, Zagarell reminds us (44), must do the work of flattening the historical account and obscuring the effect of specific historical forces. Matrifocalism, for instance, lends itself to reading for mythic and symbolic valence. Quite a few feminist critics were able to discover a plentiful and strong mother-daughter connection, notable especially in the axial relationship in Jewett's text—-that between Almira Todd and her mother, Mrs. 
Blackett, and replicated in the intimacy developing between Mrs. Todd and the narrator.

The skewed gender balance of the society and its organic mold reflect an image of a place that "seemed to have 'escaped' the dubious improvements of a stronger and more integrated urban economy" (Foote 3). A misleading perspective, when taking into account that the scarcity of men (women's graves predominate at a local graveyard) is due to their perishing at sea, in wars, or to their western migration. When it comes to the economy, the novel renders an image of an erstwhile economically robust region-relying on the cycles of trade and whaling - that now suffers long-term decline, which brings the unintended and dubious benefit of "eluding the potential ravages of modernity" (Foote 3).

Even when the narrator monumentalizes time and seeks to mythologize her characters, this freeze-frame serves rather the purpose of aggrandizing the particular unifying racial past of the region and seeks to solidify its claims as an authentic kernel of the nation, sounding "the late $19^{\text {th }}$-century's anxieties about national identity and citizenship" (Foote 3). At first, we might be baffled by the idea that a sterile, depleted, economically backward, and pre-modern region filled with old and elderly people could be reinvented as a repository of "a common national past," with its "folk" serving "as doubles of foreigners, or immigrants," as argued by Foote (6). The arrest of time, however, in its pastoral or mythic guise, allows Jewett, and her genteel urban and national readership, to construe a powerful narrative of the common past in the face of the contiguous but distinct forces of mass immigration and imperialism (Foote 13), to which we must add industrialization.

For both these processes, as Holly Jackson contends, Jewett needs a specific idea of race, be it in the form of an invented racial past or a mythic recombination of the extant elements (especially in the connection between nature and women, so that pastoralism is here gendered as feminine). This re-imagining was needed in particular after the Civil War when racial homogeneity of New England was undermined (Jackson 267). As Ammons notes, the recuperation of the region's (in extension, the nation's) enabling past occurs in Jewett's historicist imagination, flourishing most flagrantly in her quaint history of the Normans, in which she blended myth, history, and fable in a narrative of a stern but superior breed of people, the conquerors and warriors from the North, who 
had a hand also in what was probably the earliest discovery of America by any Europeans. As Jewett points in her "history":

Historians have been much perplexed at the fact of Leif Ericsson's lack of interest in the fertile Vinland, New England now, which he visited in 986 and praised eloquently when he left it to its fate. Vinland waited hundreds of years after that for the hardy Icelander's kindred to come from old England to build their houses and spend the rest of their lives upon its good corn-land and among the shadows of its great pine trees. (The Normans 18)

It is important to note how Ericsson's presumed report resonates with the legendary accounts of the new world of plenty, which later would become the crux of the New World pastoral (Marx 34-46). Additionally, we can surmise that the character of New England's inhabitants, inasmuch as they stem from the Norsemen, is stamped by the same courage, restlessness, and love of sea-faring, as their distant descendants display them in Jewett's novel. One of the culminating events in the novel, the Bowden reunion, a gathering taking place in nature and drawing the branches of the local family together, including the narrator herself (who, therefore, is not quite so foreign as not to be embraced as one of them), is seen by Ammons as a blatant celebration of a particular idea of the common past: "the ritual celebrates not just rural life but specifically the transplantation of Anglo-Norman culture onto North American soil" (92). Even as Ammons next contends that despite the region's obvious decline Dunnet Landing still occupies "the center of a far-flung empire" (93), my reading is somewhat different, and finds the projected vision of the past grandeur delimited precisely by the pastoral co-ordinates: the time out of place, replayed as a distant, mythic past and in a natural space rendered equally vague. ${ }^{5}$

The issues of racism and imperialism remain an on-going contention in Jewett's criticism. For an outline of the debate on Jewett's investment in or distancing from the prevailing discourse of race and (domestic and international) imperialism, see Donovan who, in my view correctly, makes careful distinction between "romantic racialism" and stereotyping observable in Jewett's "Nordicism" (409) and the racist discourse underpinning imperialist and military ventures at the time or branding immigrants as undesirable. For an equally nuanced and well documented approach, see Heller. 


\section{From Pastoralism to Regionalism}

If, as has been argued, the turn-of-the-twentieth-century literary regionalism would wear the cloak tailored, among others, by the pastoral ideal, and thus seek to obfuscate and marginalize the matters of the social context, more particularly, politics, the market forces, societal upheavals, culture conflict, and social and geographical mobility that were ripe in American society of the time, then this escapism is in itself a telling indication what to look for, not only in Jewett's text but also in other texts forged in this tradition. When regionalism hosts pastoralism, so to speak, the latter becomes mired in its own "internal contradictions," as pointed out by Buell (31). Buell usefully pinpoints the association of pastoralism and regionalism that holds valid not only for Jewett's literary effort but also, as the continuing discussion intends to show, for contemporary novelist, Elizabeth Strout's venturing into the same field: "The modern transmutation ... is the enlistment of pastoral in the service of local, regional, and national particularism" (Buell 32). This will allow us to extend our inquiry into the millennial moment, as we look at how depopulation, depletion, out-migration, ageing population, and economic stagnation affect the coastal Maine.

Finding ourselves at another turn of the century and a little beyond it in post-9/11 America as an implicit backdrop of Strout's stories, is it possible to locate and identify a lingering legacy of pastoralism and to gauge its contemporary political purchase? That this is not such a preposterous idea is signaled by Leo Marx's comment in the epilogue to his book about the enduring effects of pastoralism in American culture and imagination: "the ancient ideal still seizes the native imagination. Even those Americans who acknowledge the facts and understand the fables seem to cling, after their fashion, to the pastoral hope" (355). Strout's novel came out in an auspicious moment as testified by the fact that it garnered the Pulitzer Prize for 2009, thus putting the regional (New England) fiction back on the national map. In a recent study, Jason Arthur notes that "regional fiction has lately started to matter to literary culture," as he then points to a striking fact of major national literary prizes in the first decade of the 2000s going to the works with regional thematic, to the works which, just like Olive Kitteridge, "feature small town socio-economic histories and reflections of aging among the debris of past vitality" (90). ${ }^{6}$ 
The other concept that allows us to shed light on the issues of old age and ageing is the concept of critical regionalism, where Strout's work shares some traits with other New England regionalists of the late modernity. In a recent article, Marleen Schulte ascribes to critical regionalism the ambition to connect global themes with local particularities (reminiscent of Buell's observation above), as a host of writers (Strout included) represent "a thus far demographically and iconographically unprecedented New England." Focusing on the still underrepresented locales (even in the ambit of New England) in its northern part (Vermont, New Hampshire, and Maine), Schulte contends that these writers aim at reconceptualizing the culturally barren regions labelled "a land of half-civilized hillbillies."

Additionally, Philip Fisher's insight is valuable as an indicator of the semantic change encompassed by the term. As Fisher claims, "in America regionalism's real alternative is mobility, change over time...." Even more pertinent for this discussion,

Mobility includes the right to go somewhere else and to be someone else, the right to start over, the option that the young above all have to make what is called 'a fresh start.' It also includes the right of children on their way to adulthood to select from, discard, forget, and create their own emphasis with the many things inherited from parents.... (Still the New World 171)

If we understand mobility and the individualist impulse to mobilize the resistance to regionalism, we are then in a position to observe Strout's characters divided into two camps, those engaged in the process of "creative destruction" (Fisher's term) in their flight from the region and those immobilized in it. The generation gap, or clash of generations, another popular and apparently ubiquitous term (which characteristically is absent from Jewett's image of the Maine village of Dunnet Landing), renders itself visible in the contrasting models of identity acquisition and maintenance through either primordial or voluntary attachments.

It is precisely these two attitudes to place-one that requires the long commitment (primordialism, permanence) and the other that wishes to do away

know" that a sequel to Olive Kitteridge is due in September 2019. In the wake of Olive Kitteridge's splashing success, the HBO series by the same name was released in 2014, starring Frances McDormand and garnering eight Emmy awards ("Olive, Again"). 
with it (voluntarism, mobility)—-that might account for this major cultural shift. Just as we could say for Jewett's Dunnet Landing, Maine, "this is the country for old folks," and appreciate the myriad ways the elderly and the old appear as characters and hypo-narrators of the cycle, and an integral part of the cultural landscape, so we could equally reasonably claim that the coastal town of Crosby, Maine more than a hundred years later is "no country for old men," to paraphrase Yeats ("Sailing to Byzantium"). ${ }^{7}$ Strout's rural Maine is also populated by elderly and old people, but other generations interact uneasily with them. The old, however, are no longer a repository of wisdom or the holders of history to whom the community looks up, nor are they cast as a source of narrative empowerment, as in Jewett's stories.

In order to consider the novel's attitude to pastoralism, we need a broader view of the phenomenon than proffered so far. Strout's text may therefore be read as, what Gifford calls a post-pastoral text. ${ }^{8}$ Whereas the focal place for Jewett's country is Almira Todd's house with the garden where she grows medicinal herbs, processes them, and procures medical advice to the community (Zagarell 44), in Strout's novel, lacking a clear center of gravity, one of the key settings was (but no longer is) a local pharmacy run by Olive's husband Henry Kitteridge until his retirement, when it is, appropriately for the times, turned into "a large chain drugstore with huge glass sliding doors" (Strout 15). Additionally, we witness the process of regional diminishment consumed in its entirety as Maine is turned into a popular tourist destination and a site of vacation, against which the drama and life of the local characters unfold. Strout, in a nod of

It is notoriously difficult to posit a cause for such a remarkable cultural shift, but a few observations are in order. As Simone de Beauvoir contends in her encompassing study of old age and ageing, the demographic shift places the topic of age on the agenda, since the period from 1900 to 1930 in the United States (so beyond the scope of Jewett's text) saw the doubling of the number of old-age persons; the similar happened also from 1930 to 1950. Needless to say, the trend only intensified in the course of the century. Next, the concentration of old people in the cities made the problem noticeable, if nothing else (29). The field of geriatrics took off in the States in the early twentieth century, not earlier (28). The period of Jewett's writing is then still idyllic and pre-scientific, a time in which old age is not conceptualized as a problem, either social, economic, cultural, or biological.

$8 \quad$ I use Gifford's term here, in particular his understanding that the contemporary reader enters into a dialogue with a pastoral- or nature-themed text with wariness, irony, and mediated knowledge of nature. Nature is often framed as 'environment', rather than 'countryside' or 'landscape' or the 'bucolic', but we cannot pretend that there have not been changes in our knowledge, attitudes and ideology" (147). Post-pastoral recognizes the potential of representing nature, and celebrating it, even as it then seeks to mount "a ... critique of the pastoral mode that is aware of its relativism, of the choices available, of its honourable and its dishonourable traditions" (148). 
recognition to her artistic predecessor, Jewett, makes the retired math teacher, Olive Kitteridge, the focal point of her novel. The parallels notwithstanding, the differences are telling too. When we consider the status of the focal characters, Mrs. Todd's mythic role is reinforced by the tending of her garden and by its communal role-the medicinal herbs grown there benefit the whole village. Olive Kitteridge is also close to the chthonic; she cultivates a garden, has an eye for plants-wild and home-grown, is attuned to the natural cycles of planting, growth, flowering, decay, and rot, but her expertise does not resonate beyond the limits of her plot of land; not even her daughter-in-law is responsive to her gardening lessons (“Tulips").

In Strout's novel, early-twenty-first century Crosby, Maine, populated by Olive Kitteridge, her family, and neighbors, and traversed by returnees, tourists, and retirees is no longer vibrant, nor self-conscious of its former glory; it is a fake pastoral haven to which the urbanites flock to temporarily flee the city. The social landscape of the semi-rural place, however, carries its own dark secrets and rarely offers serenity and rest that might have been expected. It is also a place from which the local younger population flees in search of other, more viable locations: Olive's son Christopher and her daughter-in-law migrate to California to Olive and Henry's utter dismay, while then her son relocates to New York City with his second wife. The fault line in this social landscape now shifts to the questions of security and vulnerability of the national space. Maine now becomes a secluded and ostensibly safe spot in a nation invaded by post-9/11 anxiety, but nevertheless filled with anxieties of its own. What Strout's brand of regionalism brings us, then, is an ongoing repositioning of the local and the global, the center and the periphery in an interconnected world (Arthur xiii). Labelling this intertwining "regional cosmopolitanism," Arthur contends, "[t]his kind of regional sensibility - the kind that redeems provincial America without being nostalgic about it ... expresses deep local affiliations without falling prey to the fallacy of thinking of one American place as more or less 'American' than another" (xviii). Rather, "it also engages global, ethical issues as they are lived in specific places and does so in a way that reveals interregional similarities that might otherwise go unnoticed" (Arthur xviii).

Given that the pastoral no longer relies on the evacuation of time and history (but rather, as in Strout's text on the irruption of them), once the quester has reached her retreat, it is consequently much more difficult to find the balance of man and environment, the self and the community, that is so important for 
the pastoral mode. The retreat no longer may bring peace, self-understanding, healing, or the cancellation of desires (from sexual to other appetites), since the reality principle invades the pastoral space. Death, deprivation, loneliness, illness, infirmity, betrayal, alienation, and corporeality have become dwellers in the pastoral space, which is now just a vague idea, the lingering feeling on the borders of Strout's text. The reader retains the faint but fading idea of the pastoral as a long-gone, bitter-sweet memory when she turns to Strout's characters. The old age can no longer be a semantic node to carry the philosophical and epistemological project of the book (as we have seen in Jewett), but is only an element on the local canvas. Jewett's narrator draws to herself a number of story-tellers, acting as repositories of social and historical knowledge of the locale, and the reader is finally made to understand that the result of her summer-long stay in Dunnet Landing, away from the confusion of the city, is precisely a string of stories that we are reading. Strout's narrative method is multi-focalization where Olive gets to be center-stage in some of the stories, but is then a minor character in others. The deliberate fragmentation fails to produce an overarching vision.

\section{Age and Emotions}

The arguments in the previous sections are meant to show that the two texts, more than a hundred years apart, are linked by the overt use of or covert references to the pastoral myth, which places them squarely in the long line of American place-based writing. This writing was distinguished by its particular reworking of the concept of temporality and the idea of space. By employing the elderly and old people as their characters, narrators, hypo-narrators, and focalizers, both texts were able to contain specific, context-bound anxieties and render them palatable and narratable to their respective audiences, all the while drawing attention to the generative pastoral design in the background. This section of the essay will take up another aspect of age in the texts that might show further divergences and thus allow us to consider the pace and scope of changes in the period under consideration, namely, the question of emotions and emotional attitudes tied to age and ageing.

To put it in very crude terms at the outset, it feels different to be old in Jewett's Dunnet Landing than in Strout's post-millennial Maine, but what exactly does that mean and how can emotions chart a trail of historical and societal changes wrought in this period? In other words, how has the "longevity revolution" (Statistical Panic 68), that silent but inexorable social process, affected the re- 
presentation of age in the foregoing text (we have to assume that this precisely is the key aspect for Strout and for our times)? By mapping emotions in the contemporary work of literature, we may be able to examine how precisely emotional states may be considered as social, and socially communicable, facts. As Fisher contends in The Vehement Passions, it is Aristotle's study of tragedy that makes us see how "by means of the relations between fear and pity . . . a civic component enters into the highly self-centered and self-defining vehement states. .." (3; emphasis added). Furthermore, insofar as the vehement states show fascinating stability across time and various cultural stages, their examination approximates "the common sense" of a civilization, to paraphrase Fisher (Vehement Passions 4).

From the delineation of strong emotions, we have reached what Fisher terms "therapeutic, post Freudian culture" (Vehement Passions 172), where we experience and discharge emotions of a different intensity, more appropriately designated as feelings, states, and moods (Vehement Passions 149). Dispassionate emotional culture, so to speak, distrusts strong emotions and seeks to level our emotional responses to a standard of normalcy. Olive Kitteridge acts contrary to these therapeutic restrictions and thereby seeks to retrieve the true passion, the kind that can enact a binding civic tie in the contemporary period. Importantly, it is by the display of passions, strong emotions such as anger, fear, grief, shame, and joy, according to Fisher, that a social realm gets to be constituted. As Fisher admonishes, passions do not have an "egocentric role" merely since "the philosophical account of the passions always included the idea that the passions are incited by what occurs within a world of care and concern-parents, children, friends, those loved or close to us-as well as by what happens directly to us" (Vehement Passions 174). Again, one needs to highlight the social aspect of emotional culture. As Woodward contends, the contemporary culture imposes "the damaging effects of the cultural prohibition of anger in older people in the United States" (Statistical Panic 59), the prohibition constantly violated by Olive.

Olive is a passionate character, in the definition meant above, proverbially a difficult person, quite irascible, querulous and grumpy, which in Fisher's model of emotions leads to Aristotle's concept of "just anger," anger that limns the boundaries of one's private and social world. "The capacity for correct anger," Fisher argues on cue from Aristotle, is a virtue possessed by a "good-tempered" man (Vehement Passions 173). As Aristotle claims, "The man who is angry at the right things and with the right people, and, further, as he ought, when he 
ought, and as long as he ought, is praised" (qtd. in Vehement Passions 173). Any reader of Strout's novel will readily recognize Olive's self-righteous, impulsive, and opinionated attitudes, but will also appreciate them as a disposition that in the closely-knit local community both sets down the boundaries between the self and the other and serves as a purveyor of justice. In other words, when Olive acts excessively and passionately, as a "good-tempered" woman, she outlines the value of her social instinct and the extent of her social sphere-drawing into her compass the people she deeply cares about.

This kind of cultural mapping of emotions in post-modern (post-emotional, therapeutic) society should be seen as very invigorating, one reason being that the current social wisdom seems to be quite uncomfortable with the cultural facts of age and ageing, and in conjunction with that, of strong emotions. Furthermore, one wonders if Strout's gerontological perspective of the region and her grumpy and cantankerous narrators (most conspicuously the titular heroine), are not a subtle protest against the rampant commodification and facile adoption of regional, local peculiarities in American fiction nowadays, a pressure created by the literary establishment eager to assimilate the fringe voices. Given the obstructed identification and the deferred readerly empathy (it takes us a while to worm up to Olive and most of the other characters/ focalizers, whether young or old), they could be seen as a cushion against an easy appropriation of yet another regional, marginal, and minority perspective. ${ }^{9}$

Woodward's study of cultural politics of emotions and ageing intends to decouple the powerful cultural myth linking wisdom (the absence of disruptive and irrational passions and emotions) and old age, and, instead to argue for a new emotional cultural script that would allow for the articulation of "a wise anger" (Statistical Panic 59). The emotional scripts as described by scholars change through our life stages, not simply as an outcome of biological exigencies (although certainly that too) but also as a result of a cultural mandate, so that ageing brings along "the loss of affect," "age anxiety," "a general self-disgust or listless resignation to a failing body," "the emotion of nostalgia" (all terms from Statistical Panic 63). Pointedly, it is this mandate that "our society draws upon to construct meaning and value, and to attempt to proscribe or valorize behavior in relation to one's age" (Statistical Panic 63). temporary regional fiction, see Arthur xiv, xv. 
Olive adheres to her own (emotional) script, and she repeatedly invalidates the cultural expectations about women and ageing, just as she has done all her life. Insofar as she has competently balanced her private and public life, she seems to have been a paragon of the modern woman as a wife, homemaker, working woman raising a child. However, in the opening story of the collection, "Pharmacy," the focalizer is Olive's benevolent, kind, and non-confrontational husband Henry, who resignedly notes Olive's "sharp opinions ... . her strong moods" (Strout 11). Even though he recollects Olive's outburst of "fury" (Strout 9), when she was overwhelmed by her chores, at home and at work, it is important not to confuse Olive's challenging character with either her working woman fatigue, her menopause (she is well past that in the narrative present), or her medical condition. It is rather the case that "emotions, the passions, need not inevitably diminish with age, and exercise-emotional exercise-is as fundamental to their vitality as is their cultural authorization" (Statistical Panic 67).

In Olive Kitteridge, we get a good glimpse of the inner preoccupations and meditations of elderly characters on, predictably, loneliness, marriage, physical and mental infirmity, and death, but also on love, desire, and sex. The idea of ageing in the postmodern era and beyond seems to have gotten so self-obsessive and self-centered, but, arguably, it is the change of focus that has made it seem so. Where in Jewett's work nobody makes a fuss about being elderly or old, mainly since the elderly people are an integral part of the local community and belong to various social networks, in Olive Kitteridge the stress is on health issues, economic burden, and emotional strain brought on by the onset of age, as increasingly medical and bureaucratic discourses are brought to bear on the issues of age and ageing (as shown in Woodward's study). It is as if the organic view of age and ageing has been replaced by a cost-and-balance model in which the expenses overweigh the benefits, both for the individual and the community.

What, then, is the place for the old in the contemporary polis? In one of the stories, Olive struggles to retain her hold on sanity after her husband Henry had suffered a stroke, and she is left to face it on her own since her son Christopher had gone to California with his wife. Hurt, resentful, and distracted, taking her daily walk along the river bank, Olive anticipates how "Rollerbladers would be passing by, young and ferociously healthy, their spandexed thighs pumping past her" (Strout 147). When she is admonished to stay on her side of the walkway, it is clear that the two groups occupy adjacent but parallel spaces, with no contact between them, and that her space is being invaded. In "Security," the pastoral 
impulse is revived, and revised in post-pastoral terms, as Olive undertakes a reverse pilgrimage, from her rural retreat to the urban commotion of New York City, where she undergoes a series of tests in which she needs to prove her spiritual resolve and strength. However, the tenor of her journey turns out to be misconstrued; the family where she is received is far from the domestic ideal that Olive fantasizes about, and mundane trials that she is exposed to leave her humiliated and shamed. The idealized bond between the mother and the son (Olive and Christopher) is parsed open and examined in cold, technical terms of psychology and psychotherapy. Olive's resultant anger and rage are presented as a passionate (in Fisher's sense) response to further medicalization of interpersonal relations. Olive's passion equally blasts the formulaic, standardized containment of grief (over the passing away of her husband) or melancholy over her impending death: she agitates precisely for the social, public recognition of the saliency and humanness of strong feelings. In Woodward's terms, used in a different context, Olive repeatedly violates "emotional standards or ideals" in favor of her idiosyncratic "emotional experience" (Statistical Panic 61).

In "The Piano Player," the focalizer, Angie O’Meara, “into her fifties" (Strout 49), plays a piano at the local Crosby bar and plays out her past in the course of an evening. The crux of her life, the source of failure that she feels herself to be, is her neurotic and troubled relationship with her mother (Strout 55), contrary to the sustaining intimacy between women of Dunnet Landing to which Jewett's narrator becomes privy. The structure of the story rests on the dynamics of feeling stirred up in Angie by remembering events from her past and interjecting them with the impressions of the interval during which the story takes place. It becomes clear that Angie's dominant feeling is that of pity and self-diminution, but that might be brought up by shaming caused by men in her life to which she used to acquiesce. At the end of the story, she manages to raise herself from the state of pity and diminishment because she understands the false "comfort" (Strout 58) some people take from shaming others. The recognition that she arrives to re-organizes the narrative of her life and enables her to rethink the relationship with the mother that weighs on her (Strout 60). Other stories, too, end on the note of recognition that is, certainly, far from the tragic pitch of anagnorisis, but might provide characters with a lever to re-start or reorder their lives, no matter their age or station in the stories. ${ }^{10}$

10 In other stories in the collection, the element of recognition serves to reorient our understanding of particular characters and their life stories. In "Pharmacy," for instance, the kind and elderly 
In this wide-ranging observation of the changing social scenery in the country of the pointed firs (which, inevitably, risks leaving quite a few things out), one notices another key distinction in the different registers of emotions in the two periods, the changing role of social rituals, which in their own way serve as public containers and conduits of emotions. The cohesive function of rituals has been observed upon by various critics of Jewett's work; the novel contains funerals, family reunions, social visits, all of which seem to magnify the feeling of community, anchor the individual deeper in the local context and allow even the outsider, the visitor, to entertain briefly a sense of belonging to the apparently compact community. Death, funerals, and ageing are considered part of life and are woven into the picture of communal life, such as when Mrs. Todd and Mrs. Fosdick exchange their memories of the past, their own and their folks'. The sprawling, multigenerational families supplied a buffer against old age, infirmity, and sickness and ensconced the individual in a fold of social relations. Family bonds extend across the country as we witness in the episode when the narrator accompanies Mrs. Todd and her mother to the Bowden reunion and observes how ties of blood or custom (in the case of neighbors) weave a dense safety net. Mrs. Blackett resides on Green Island, another symbolic center of the novel (Fetterley and Pryse 157), not alone but accompanied by her shy, anti-social but resourceful son William. The narrator, we come to understand, objectifies these interpersonal relations since she needs them to counterbalance the encroachments of the outside world (Fetterley and Pryse 117).

Strout's characters, on the contrary, experience an entirely different family dynamics in which the intergenerational linkages are all but broken; it is understood, and perhaps even stipulated, that young people would leave their home (to evoke Fisher's concept of "creative destruction") and, often, their local habitation in favor of urban spaces; and a low premium is put on the maintenance of close and sustaining family ties. It is a source of deep anguish but also (just?) anger for Olive the fact of being abandoned by her only child, Christopher, and in a few stories told from Olive's (tendentious) point of view, it is the fact of abandonment that rankles her and that precipitates Henry's fatal stroke: "it had been a really ghastly blow for the Kitteridges to have Christopher so suddenly

Henry Kitteridge understands that he might not be so noble and selfless as he is made out to be (Strout 29); in the next story, "Incoming Tide," Kevin, the focalizer, a young man estranged from the local community, nearly crushed by his family's history and contemplating suicide, gets to confront his deep-seated instinct for life (Strout 47). 
uprooted by his pushy new wife" (Strout 107). The changing family demographics leaves its imprint on the elderly and their quality of life, while the narrative paints the bleakness of their prospects as they face the risks of old age on their own.

These ominous associations notwithstanding, the emotional range associated with old age is in no way monochrome: Strout's characters dwell on a wide range of emotions and experiences, unhampered by their mortal coils, reinvigorated by the ingrained life instinct. It is true that Olive welcomes her own demise, after Henry's death, and begins to think more insistently about her own departure (Strout 253), but she also welcomes spring, revival of life in nature, and a new emotional and physical experience in the closing story of the collection, "River." It is the wisdom that comes from age but also seasoned by emotions and passions that still abide in the ageing body, and require a new script to be relayed and given social and cultural recognition: "there was a contest within her [Olive], revulsion and tentative desire ... as she sat down quietly, placed her open hand on his chest, felt the thump, thump of his heart, which would someday stop as all hearts do" (Strout 269). This back and forth of the Eros and the Thanatos is the very stuff of life, but is here certified by experiential stamp and made to dignify and valorize that aspect of human life: the old age as a thing valuable in itself and for the knowledge it brings by way of emotions and passions it stirs up, a re-engagement with life (Gruman qtd. in Statistical Panic 73). It is the mortar of strong emotions that holds together the depressed and depleted, bereaved and disheartened Olive, not only bringing her back to life but also enabling her to forge another social and personal contact.

\section{Conclusion}

The country of the pointed firs has thus undergone considerable changes of its social landscape, as reflected in the fiction committed to that locality. A fraction of those changing attitudes concern the notions of age and place (whether looked at from the point of view of pastoralism, regionalism or both), and age and emotions, as indicated here but could be extended in other directions too. Generally, the characters in late nineteenth-century Maine freely admit to sickness, frailty, and death as inevitable and as a normal course of affairs. So Mrs. Blackett announces matter-of-factly: “The time o' sickness an' failin' has got to come to all," but then adds significantly, "But Almiry's got an herb that's 464 good for everything" (Novels and Stories 419), pointing not only to Almira's li- 
fe-sustaining gift but also to their vital mother-daughter connection. Their early twenty-first-century counterparts do not share their resigned but also resilient stance since their world-view is marked by an almost pathological, medicalized, and quite melancholic view of old age bequeathed to us, without doubt, by the requirements of modern technological and bureaucratic systems enveloping every aspect of our lives, "the medical bureaucracy with its countless rules and regulations, its impersonal and methodical techniques of 'rationality', and its forms and filing deadlines" (Statistical Panic 168).

As a tentative conclusion, I would like to revert once again to Yeats's poem "Sailing to Byzantium," in which the speaker finds the way out of the prison of the mortal body ("a tattered coat upon a stick") by surrendering himself to the eternal and immobile, artificial beauty of Byzantium and its magnificent monuments to human intellect (Yeats). The speaker is confident that by renouncing the corporeal and exiting from nature ("the dying generations"), he will achieve the immorality of art, whereby he expresses the paradigmatic modernist glorification of art as superior to the unruly life and uncontainable nature (Yeats). The modernist trust and investment in art, however, while still operative in Jewett's stories and driving her narrative art, can no longer be detected in Strout's postmodern, fallen world, which once again, as by a swing of the pendulum, returns to the pole of life and human biology, acquiescing to its inexorable laws, renouncing all hope of an idealized Byzantium. Where Jewett's modernist procedure seems to discern an order behind the randomness and decay of human existence (myth, folkways, history, narrative, kinship), Strout's postmodern mapping of the local lives in national and global contexts fails to conjure sustaining elements and leaves her characters in an unredeemed world, grounded in the implacable naturalism of existence. The two texts thus present a long arch in American culture stretching from the pastoral imagination to its anti- and post-pastoral revisions and, importantly, do it through the lenses of age. Reading from that angle, we can begin to reclaim in American literature and culture the submerged narrative of ageing and begin to elucidate the ways age can be a very useful and nodal category of cultural analysis. Further, the nexus of age studies and the humanities might empower and equip the latter to more forcefully and consequentially address the indeed topical problems of today's societies. 


\section{Works Cited}

Ammons, Elizabeth. "Material Culture, Empire, and Jewett's Country of the Pointed Firs." New Essays on The Country of the Pointed Firs, edited by June Howard, Cambridge UP, 1994, pp. 81-99.

Arthur, Jason. Violet America: Regional Cosmopolitanism in U.S. Fiction. U of Iowa P, 2013.

Banta, Martha. Imaging American Women: Idea and Ideals in Cultural History. Columbia UP, 1987.

Beauvoir, Simone de. Starost I. Translated by Mirjana Vukmirović, BIGZ, 1987.

Brodhead, Richard. Cultures of Letters: Scenes of Reading and Writing in Nineteenth-Century America. U of Chicago P, 1993.

Buell, Lawrence. The Environmental Imagination: Thoreau, Nature Writing, and the Formation of American Culture. The Belknap P of Harvard UP, 1995.

Donovan, Josephine. "Jewett on Race, Class, Ethnicity, and Imperialism: A Reply to Her Critics." Colby Quarterly, vol. 38, no. 4, 2002, pp. 403-16.

Earnest, Ernest. The American Eve in Fact and Fiction, 1775-1914. U of Illinois P, 1974.

Emerson, Ralph Waldo. The Essential Writings of Ralph Waldo Emerson. The Modern Library, 2000.

Fetterley, Judith, and Marjorie Pryse. Writing Out of Place: Regionalism, Women, and American Literary Culture. U of Illinois P, 2003.

Fisher, Philip. Still the New World: American Literature in a Culture of Creative Destruction. Harvard UP, 1999.

---. The Vehement Passions. Princeton UP, 2002.

Foote, Stephanie. Regional Fictions: Culture and Identity in Nineteenth-Century American Literature. U of Wisconsin P, 2001.

Gifford, Terry. Pastoral. Routledge, 1999.

Heller, Terry. "Jewett, Nordicism, and Race." The Sarah Orne Jewett Text Project, www.public.coe.edu/ theller/soj/nor/nordicism-e.html. Accessed 10 Feb. 2019.

Howard, June. "Introduction." New Essays on The Country of the Pointed Firs, edited by June Howard, Cambridge UP, 1994, pp. 1-37.

Jackson, Holly. “So We Die Before Our Own Eyes': Willful Sterility in The Country of the Pointed Firs." The New England Quarterly, vol. 82, no. 2, 2009, pp. 264-84.

Jefferson, Thomas. Notes on the State of Virginia. Philadelphia: Prichard and Hall, 1788. Documenting the American South, docsouth.unc.edu/southlit/jefferson/jefferson. html. Accessed 10 Feb. 2019.

Jewett, Sarah Orne. The Normans. Told Chiefly in Relation to Their Conquest of England. New York: G.P. Putnam's Sons; London: Fisher Unwin, 1905. Internet Archive, ia802705. us.archive.org/5/items/normanstoldchief00jewerich/normanstoldchief00jewerich. pdf. Accessed 10 Feb. 2019.

---. Novels and Stories. The Library of America, vol. 69, edited by Michael Davitt Bell, Literary Classics of the United States, 1994. 
Lanser, Susan S. “Aging with Austen.” PMLA, vol. 133, no. 3, 2018, pp. 654-60.

Lawrence, D.H. Studies in Classic American Literature. 1923. The Viking P, 1961.

Lewis, R.W.B. The American Adam: Innocence, Tragedy and Tradition in the Nineteenth Century. Phoenix Books, 1955.

Marx, Leo. The Machine in the Garden: Technology and the Pastoral Ideal in America. Oxford UP, 1964.

McGlynn, Cathy, et al, ed. Ageing Women in Literature and Visual Culture: Reflections, Refractions, Reimaginings. Palgrave Macmillan, 2017.

Morganroth Gullette, Margaret. Agewise: Fighting the New Ageism in America. U of Chicago P, 2011.

Murray, Charles. Coming Apart: The State of White America, 1960-2010. Crown Forum, 2012.

“Olive, Again." Elizabeth Strout, elizabethstrout.com. Accessed 10 Feb. 2019.

Port, Cynthia. "Rereading the Future." PMLA, vol. 133, no. 3, 2018, pp. 640-46.

Schulte, Marleen. "Shifting Spaces in the Critical Regionalist Fiction of New England." Current Objectives of Post-Graduate American Studies, vol. 12, 2011, copas.uni-regensburg.de/article/view/139/165. Accessed 7 Jan. 2019.

Strout, Elizabeth. Olive Kitteridge. Random House, 2008.

The Sarah Orne Jewett Text Project, www.sarahornejewett.org/soj/contents.htm. Accessed 10 Feb. 2019.

Woodward, Kathleen. Statistical Panic: Cultural Politics and Poetics of Emotions. Duke UP, 2009.

---. "Re-reading Simone de Beauvoir's The Coming of Age." Age Culture Humanities: An Interdisciplinary Journal, issue 3, 2016, ageculturehumanities.org/WP/rereading-simone-de-beauvoirs-the-coming-of-age/. Accessed 3 Feb. 2019.

Yeats, William Butler. "Sailing to Byzantium." Poetry Foundation, www.poetryfoundation. org/poems/43291/sailing-to-byzantium. Accessed 10 Feb. 2019.

Zagarell, Sandra. “Country's Portrayal of Community and the Exclusion of Difference." New Essays on The Country of the Pointed Firs, edited by June Howard, Cambridge UP, 1994, pp. 39-60. 


\section{PROŠLOST I SADAŠNJOST DOBI I STARENJA U \\ ROMANIMA THE COUNTRY OF THE POINTED FIRS \\ (KRAJ ŠILJASTIH JELA) I OLIVE KITTERIDGE}

\begin{tabular}{c} 
Sažetak \\
\hline Jelena ŠESNIĆ \\
Filozofski fakultet \\
Sveučilišta u Zagrebu \\
Ivana Lučića 3, HR - 10 000 Zagreb \\
jsesnic@ffzg.hr \\
\hline
\end{tabular}

Tekst razmatra klasični roman američke književnost s konca 19. stoljeća, The Country of the Pointed Firs (Kraj šiljastih jela, 1896), spisateljice Sare Orne Jewett i roman Olive Kitteridge, spisateljice Elizabeth Strout, s početka 21. stoljeća (2008) te ih postavlja u međusobne kontekste unutar interpretacije inspirirane studijima starenja i njihove sve veće prepoznatliivosti u humanistici. Ovaj se argument potom dopunjuje pojmom pastoralizma, osobito s obzirom na to kako uključuje ili isključuje pitanja dobi i starenja. Oba se teksta potom stavljaju u kontekst regionalne proze i njezine duge tradicije osobito u prozi Nove Engleske, promatrano iz očišta dobi. Konačno, značajne sličnosti ali i razlike između oba teksta nadaju se razmatranju na koji način različiti vremenski i kulturni konteksti utječu na prikaz osjećaja i njihova izražavanja u njima. Promotrene razlike ilustriraju na koji način pitanje starenja, i njegove brojne popratne pojave, utječu na suvremena zapadna društva. Oba teksta, dakle, pokazuju prijelaz u američkoj kulturi od prikaza dobi i starenja u predznanstvenoj fazi (Jewett) do suvremenoga medikaliziranog i znanstvenog pogleda na starost i njezine posljedice (Strout).

Ključne riječi: studije starenja, The Country of the Pointed Firs (Kraj šiljastih jela), Olive Kitteridge, pastoralizam, regionalizam, emocije 